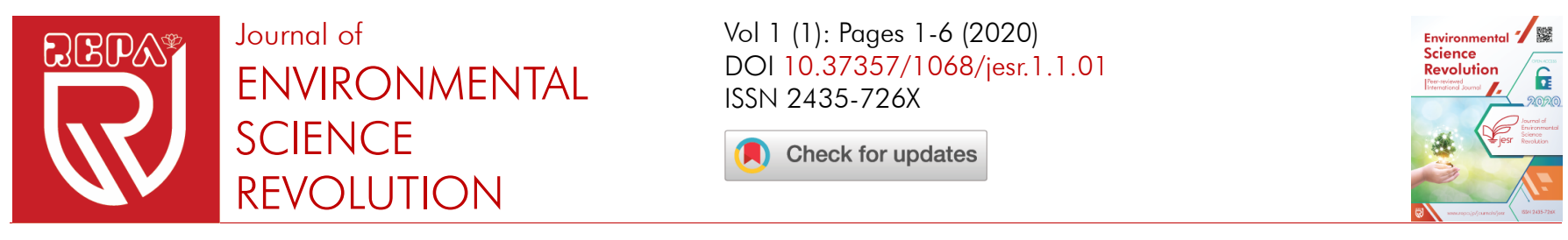

\title{
Evaluating stream bank instability and toe erosion using BSTEM model for the Amu river
}

Mohammad Omar Rasouli ${ }^{1}$, Sayed Hashmat Sadat ${ }^{1}$ and Stefanos Xenarios ${ }^{2}$

${ }^{1}$ Department Department of Civil Engineering, Faculty of Engineering, Kabul University, Kabul, Afghanistan

${ }^{2}$ Graduate School of Public Policy, Nazarbayev University, Astana, Kazakhstan

Special Issue Article

Open Access

Published

Keywords

- Stream bank erosion

- Stream bank stability

- BSTEM

- Bank toe erosion

- Amu River

\section{ABSTRACT}

Loss of land, disputes on sharing costs, and benefits of transboundary waterways are points of debate between neighboring countries. Unfortunately, weak, undeveloped countries always suffer more than their stronger neighbors. Due to economic, political, and institutional problems, Afghanistan is one country that faces challenges to develop the potential of its water resources. Each year, Amu River flooding causes great losses of land due to massive bank degradations and erosions for up to several kilometers. Currently little progress has been made to study, research, or manage the bank erosions of the Amu River. In the absence of field data, the Bank Stability and Toe Erosion Model (BSTEM) may be used to analyze stream bank stability and toe erosion. This study was conducted to describe the Amu River stream bank using the BSTEM model for a restoration process. A field survey was conducted from February 3, 2019, to February 23, 2019; soil type, layer thickness, water table depth, and stream bank profile are entered into the BSTEM model with two different flow depths according to insights from villagers and well-diggers. Mass failure and toe erosion are two dominant mechanisms of Amu River bank failure, and the effectiveness of vegetation on bank protection is observed.

Received: November 11, 2019; Revised: December 18, 2019; Accepted: March 20, 2020; Published: June 05, 2020

\section{Introduction}

Channel migration and meandering are natural processes by which a river dissipates its energy during floods and plays a role in landform evolutions. Due to erosion, rivers are always transporting and depositing sediments downstream. Consequently, a lot of money has been spent to stabilize stream banks [1,2].

Each year Afghanistan suffers from the loss of land due to massive bank degradation and erosion along the Amu River. In some places, the river erodes several kilometers of land and property each year. To avoid losing the land, a safe, economic approach to control the migration of such rivers is necessary [3]. Recently stream bank models have been used to evaluate the stability of the bank and investigate solutions for bank stabilization. To evaluate stream bank instability and bank toe erosion, HEC-RAS software has been used as a powerful tool for modeling [4]. iRIC has different features to model stream bank erosions and stability issues [5]. But, based on the authors experience, both HEC-RAS and iRIC models need more detailed data such as the cross-section of the river, flow data, sedimentation, bed load data, and angle of repose. The present study is limited due to lack of access to reliable data sources. The Amu River is so wide, and the flow data is said to be unavailable; our efforts to receive any data from the Afghan Ministry of Energy and Water were unsuccessful. Therefore, in this study, the BSTEM model is used with data from field visits. Bank Stability and Toe Erosion Model (BSTEM) has two components to calculate a safety factor $\left(\mathrm{F}_{S}\right)$ for stability of stream bank.
The purpose of this paper is to propose the application of the BSTEM model for observing and quantifying the stream bank and toe erosion for the stabilization process.

\section{Study Area}

Study area is a segment of the Amu River that is located in the north of the Shor Tepa district of Balkh province. In the Shor Tepa district every year, the Amu River sweeps several hectares of land due to massive bank erosion. The latitude of the stream is $37^{\circ} 21^{\prime} 27^{\prime \prime} \mathrm{N}$ and the longitude is $66^{\circ} 59^{\prime} 15^{\prime \prime} \mathrm{E}$ (Figure 1). The altitude of the study area is $274 \mathrm{~m}$. The area is covered by grass and bushes and is characterized by lands such as agricultural, brash, baron, and urban areas (Figure 2).

\section{Methodology}

The Bank Stability and Toe Erosion Model (BSTEM) was developed by the National Sedimentation Laboratory in Oxford, Mississippi, USA [6]. BSTEM computes a safety factor ratio $\left(\mathrm{F}_{S}\right)$ of driving forces to resisting forces of the failure plane to evaluate the stability of the stream bank. When the driving force applied on bank exceeds the resisting forces, geotechnical failure occurs. This model calculates the safety factor using several methods: vertical slices, horizontal layers, and cantilever shear failures, and it considers iteratively several failure planes until the failure with the lowest safety factor is determined. 


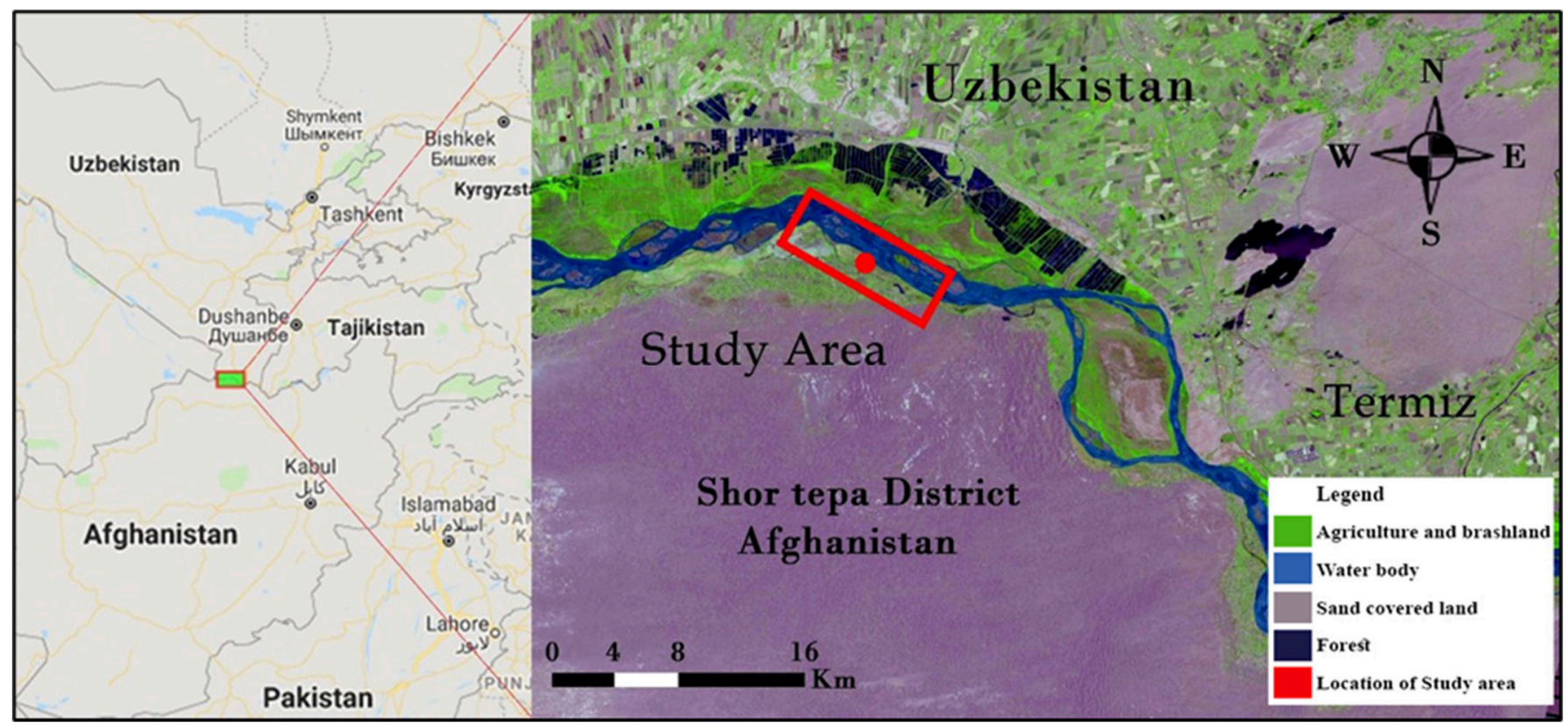

Figure 1. Location of study area in Amu river [7].

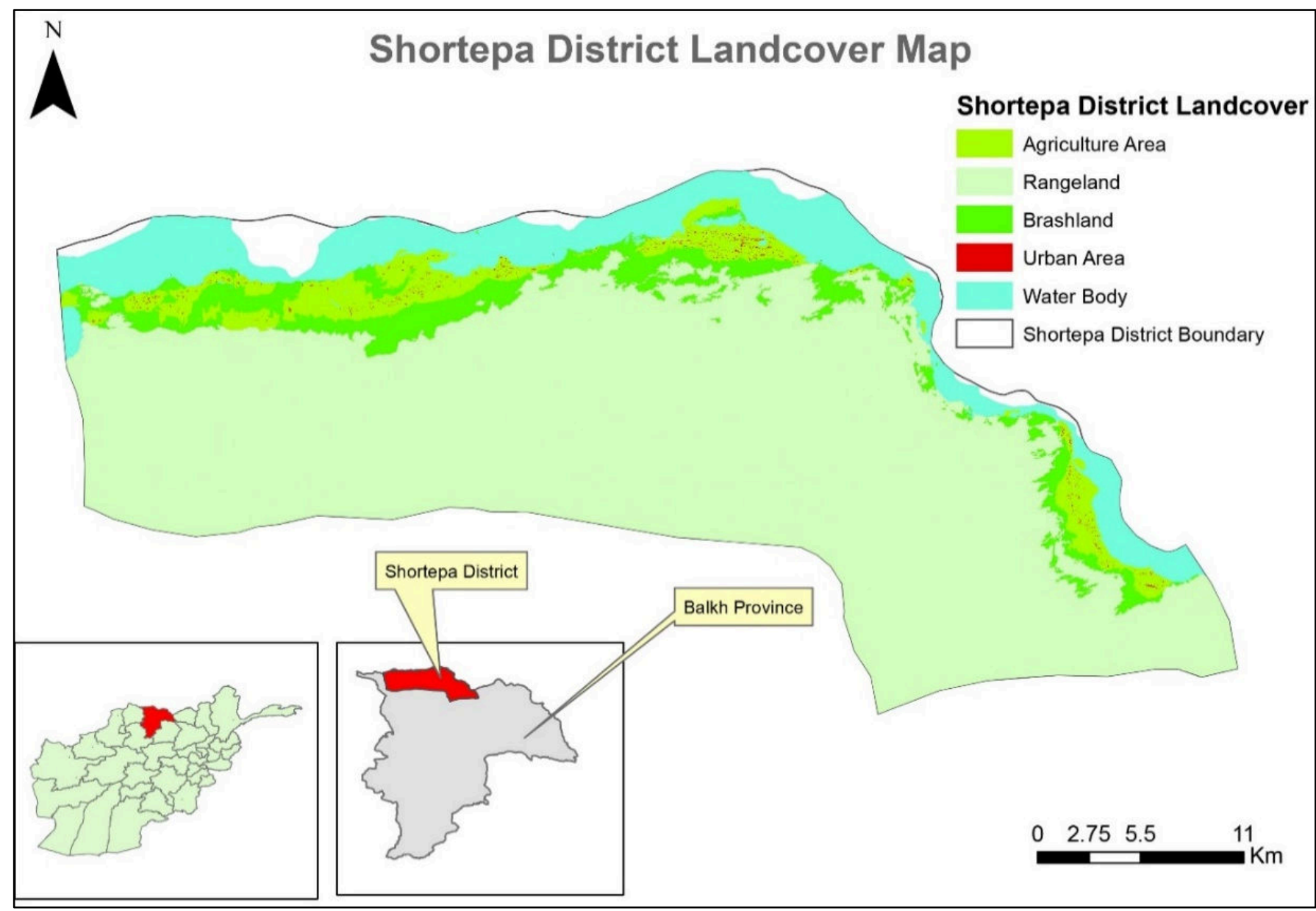

Figure 2. Shor Tepa district land cover map [8].

The model uses the excess shear stress equation to quantify the erosion rate:

$\varepsilon_{\tau}=k_{d}\left(\tau-\tau_{C}\right)^{a}$ where $\varepsilon_{\tau}$ is the erosion rate (in $\mathrm{m} \mathrm{s}^{-1}$ ), $k_{d}$ is the coefficient of erodibility (in $\mathrm{m}^{3} \mathrm{~N}^{-1} \mathrm{~s}^{-1}$ ), $\tau$ is the average applied shear stress (in pascals), $\tau_{C}$ is the critical shear stress (in pascals), and $a$ is an exponent assumed to be one [6,9] . Geotechnical parameters are extremely important and 
highly variable to determine bank stability; the safety factor is highly sensitive to cohesion $C^{\prime}$, and friction angle $\phi^{\prime}$. BSTEM also gives default geotechnical parameters that are available for a very limited selection of soil types: gravel, sand and gravel, sand, loam, and clay [10]. The first step to using the BSTEM model is entering bank profile data, bank layer thickness, and flow information into the "Input Geometry" tab. Five layers of soil with soil type can be entered (Figure 3). Bank profile, flow information, soil type, and their thickness are also entered to the model. For estimating critical shear stress of soil, duration of flow, reach length and its slope, and elevation of flow are entered to the model [11].

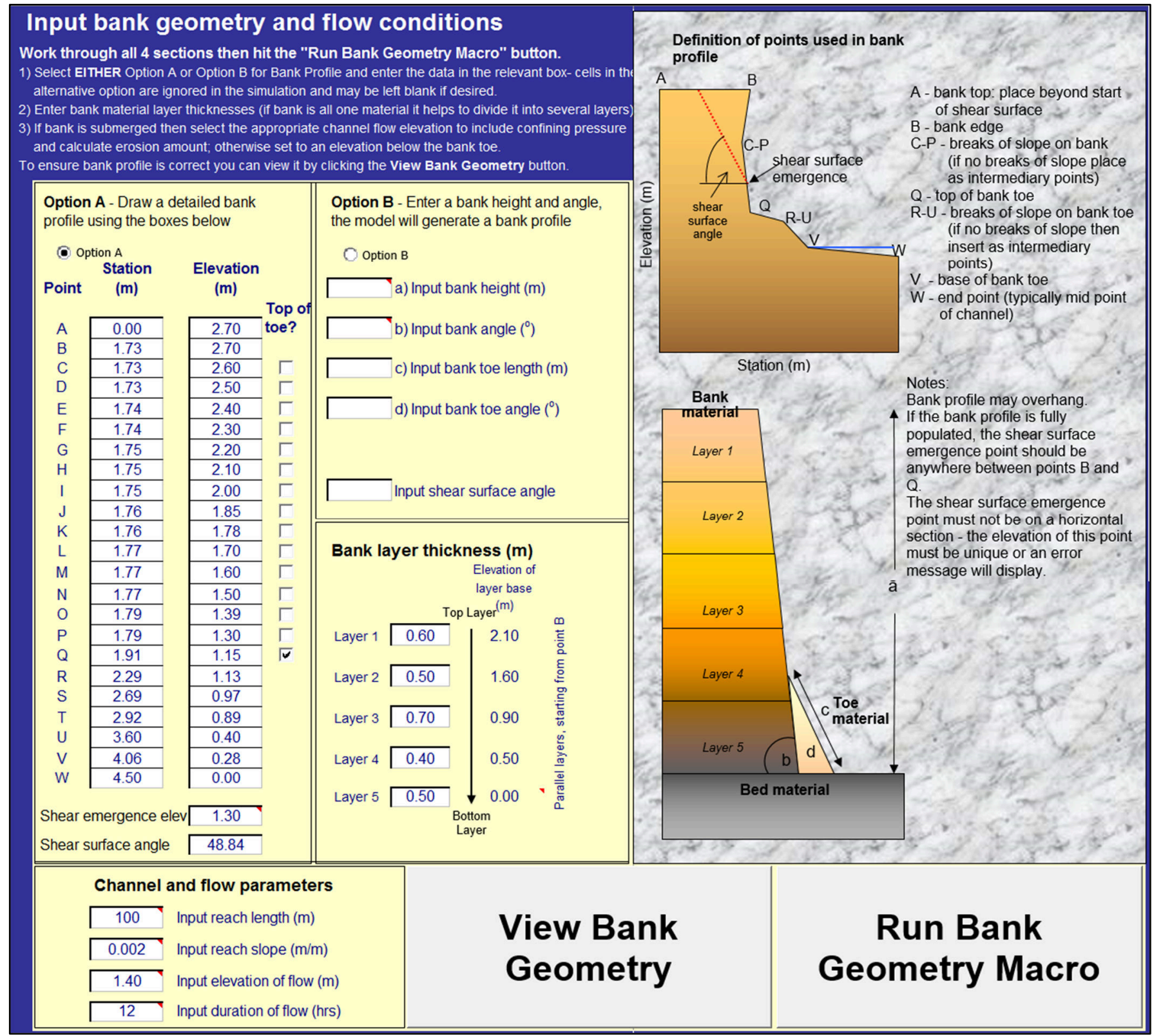

Figure 3. Input geometry data into BSTEM model.

The water table depth can be inserted in the «Bank Model Output » tab. The outputs of the bank stability model are new geometry, safety factor, and shear surface angle. If the safety factor Fs is greater than 1.3 , the bank is stable. Banks with the safety factor of 1.0-1.3 are «conditional stable». If the safety factor is smaller than 1.0, failure will occur, and a new bank geometry appears. With BSTEM we can export a new or failed profile into the model and run the model again. The other component of BSTEM is bank toe erosion that can calculate eroded bank area, eroded bank toe area, total eroded area, maximum lateral retreat, eroded bed area, applied boundary shear stress, and new geometry. In bank stability model, the eroded profile can be exported to run the model again. BSTEM can also demonstrate the effect of vegetation with root-reinforcement. 
The output of the root-reinforcement model adds cohesion due to the root system [10]. Since the Shor Tepa district is under control of the Taliban, it was not safe to carry out some field investigations. However, in February 2019, we managed to interview some villagers by phone and asked them to take some photos and videos to capture the most extreme cases in their home villages. We also contacted a person who has been digging water wells in the area for more than 10 years in different villages. According to his experience, we were able to obtain the soil type, layer thickness, and water table information.

As seen in Figure 4, BSTEM model was used with the following steps:
1- The Toe-erosion model was run and new data was exported to the model.

2- The bank stability model was run after clicking on the bank geometry macro.

3- If the failure occurs, a new bank profile is exported, and then toe erosion model is evaluated.

4- If failure does not occur, the bank profile is not exported, and then toe erosion model will be evaluated under these conditions:

5- If no failure occurs, then the running procedure will end after 5 trials.

6- The analysis procedure will end if the safety factor is higher than 1.1 after an instability event.

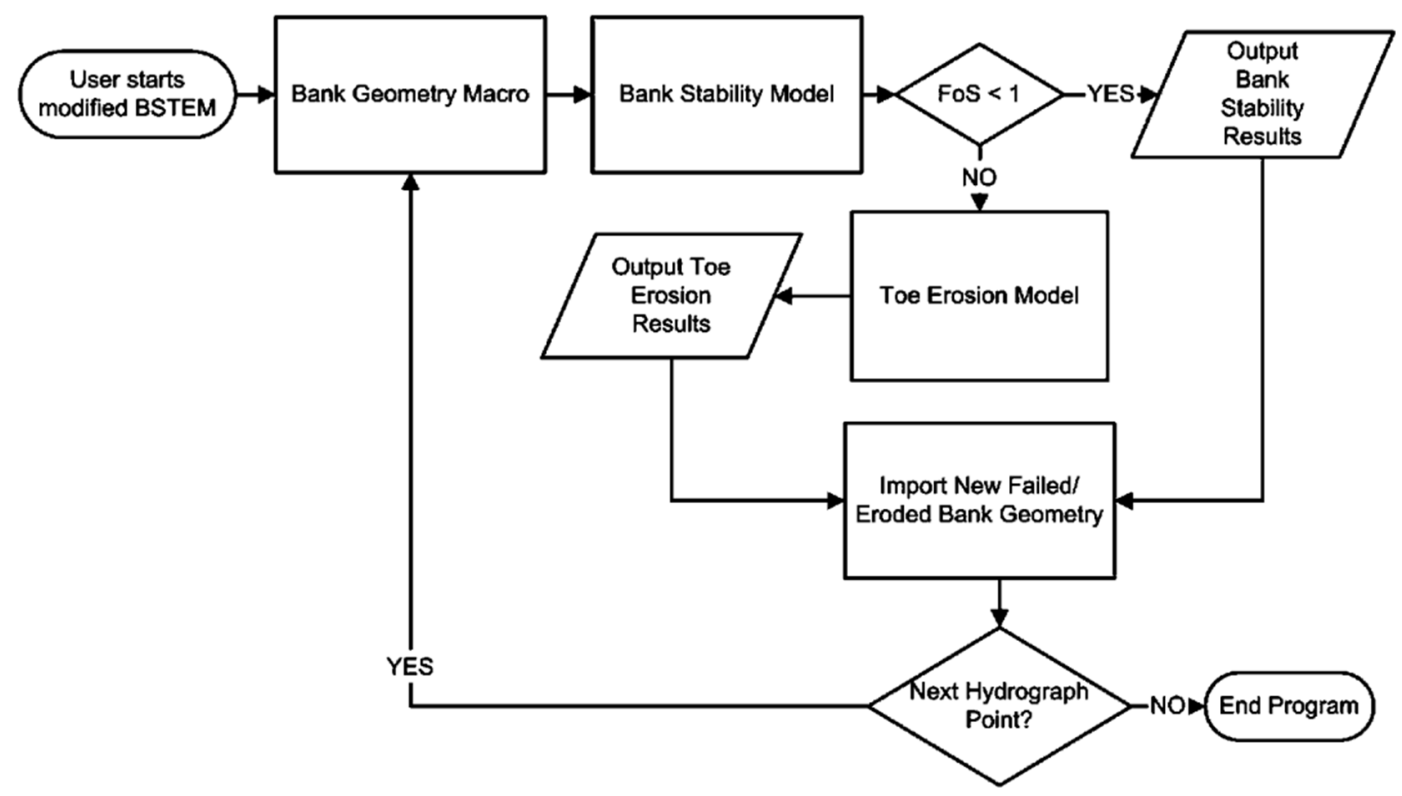

Figure 4. A flowchart for Running the BSTEM model.

\section{Input Data}

Field survey activities were done in order to locate and measure the eroded river bank sectors. Figure 5 shows a field observation profile and stream bank material. Water table depth was defined $3 \mathrm{~m}$. Reach slope was entered as 0.002 . The model then was run for two different flow depths ( 1 and $1.4 \mathrm{~m}$ ) for 12 hours flow duration.

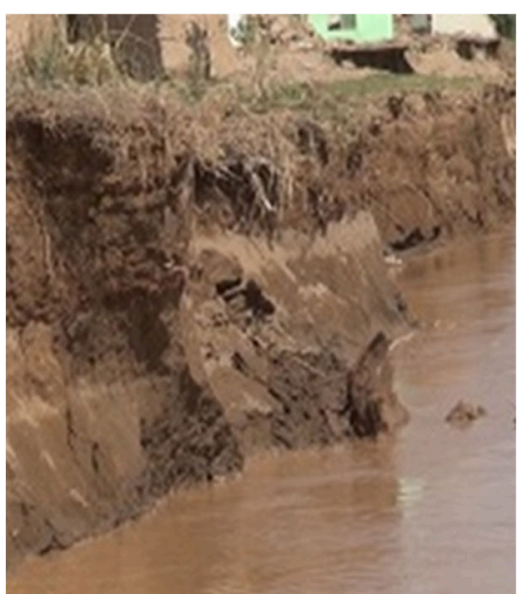

Figure 5. The photo depicts the stream bank at the study area. 


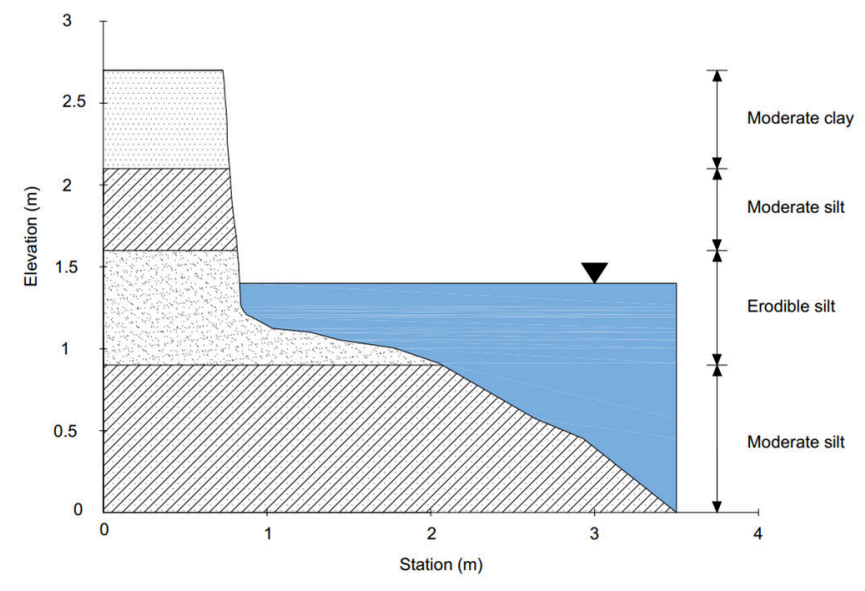

Figure 6. Stream bank profile according to the interrogation.

\section{Results and Discussion}

The analysis shows that the critical scenario happens with the highest flow depth. After three iterative runs, the stream bank had an $F_{s}=0.93$ determined as unstable. After the failure occurred, the model gives a new geometry. After each run, the new geometry data that was saved to a file clearly shows failure at each time step and at initial and final conditions. Processing of the running procedure continued until the safety factor reached Fs $=1.44$, which is after five iterations of the toe-erosion model. Table 2 shows the results obtained from the toe-erosion model. All geometry data were represented in a graphical view (Figure 6) to see the failure mechanism of the stream bank. The graph shows the hydraulic erosion and geotechnical erosion at each time step.

Table 1: Stream bank soil type and thickness (assumed based on an interview with villagers and well diggers).

\begin{tabular}{lll}
\hline Layers & Soil type & Thickness \\
\hline Layer 1 & Moderate clay & $60 \mathrm{~cm}$ \\
Layer 2 & Moderate silt & $50 \mathrm{~cm}$ \\
Layer 3 & Erodible silt & $70 \mathrm{~cm}$ \\
Layer 4 & Moderate silt & $90 \mathrm{~cm}$ \\
\hline
\end{tabular}

Table 2: Stream bank Toe-erosion model output.

\begin{tabular}{|c|c|c|c|c|c|c|c|c|}
\hline $\begin{array}{l}\text { Flow depth } \\
\text { (m) }\end{array}$ & $\begin{array}{l}\text { Flow duration } \\
\text { (hr) }\end{array}$ & $\begin{array}{l}\text { Tension crack } \\
\text { (m) }\end{array}$ & $\begin{array}{l}\text { Applied shear } \\
\text { Stress (Pa) }\end{array}$ & $\begin{array}{l}\text { Max lateral } \\
\text { Retreat (m) }\end{array}$ & $\begin{array}{l}\text { Bank eroded } \\
\text { Area }\left(\mathrm{m}^{2}\right)\end{array}$ & $\begin{array}{l}\text { Bank toe } \\
\text { eroded area } \\
\left(\mathrm{m}^{2}\right)\end{array}$ & $\begin{array}{l}\text { Bed eroded } \\
\text { area }\left(\mathrm{m}^{2}\right)\end{array}$ & $\begin{array}{l}\text { Total eroded } \\
\text { area }\left(\mathrm{m}^{2}\right)\end{array}$ \\
\hline 1.4 & 12 & 1.5 & 10.15 & 6.3437 & 0.0186 & 0.0894 & 0.0104 & 0.1184 \\
\hline 1.4 & 12 & 1.5 & 10.52 & 8.2924 & 0.0269 & 0.0917 & 0.0097 & 0.1282 \\
\hline 1.4 & 12 & 1.5 & 9.46 & 7.4531 & 0.0378 & 0.0963 & 0.0087 & 0.1428 \\
\hline 1.4 & 12 & 1.5 & 10.19 & 11.6673 & 0.0550 & 0.0973 & 0.0078 & 0.1601 \\
\hline 1.4 & 12 & 1.5 & 10.59 & 14.6421 & 0.0698 & 0.0911 & 0.0067 & 0.1677 \\
\hline 1.4 & 12 & 1.5 & 10.44 & 14.7352 & 0.0485 & 0.0953 & 0.0056 & 0.1494 \\
\hline Total & & & 61.35 & 63.1338 & 0.2567 & 0.5611 & 0.0488 & 0.8666 \\
\hline
\end{tabular}

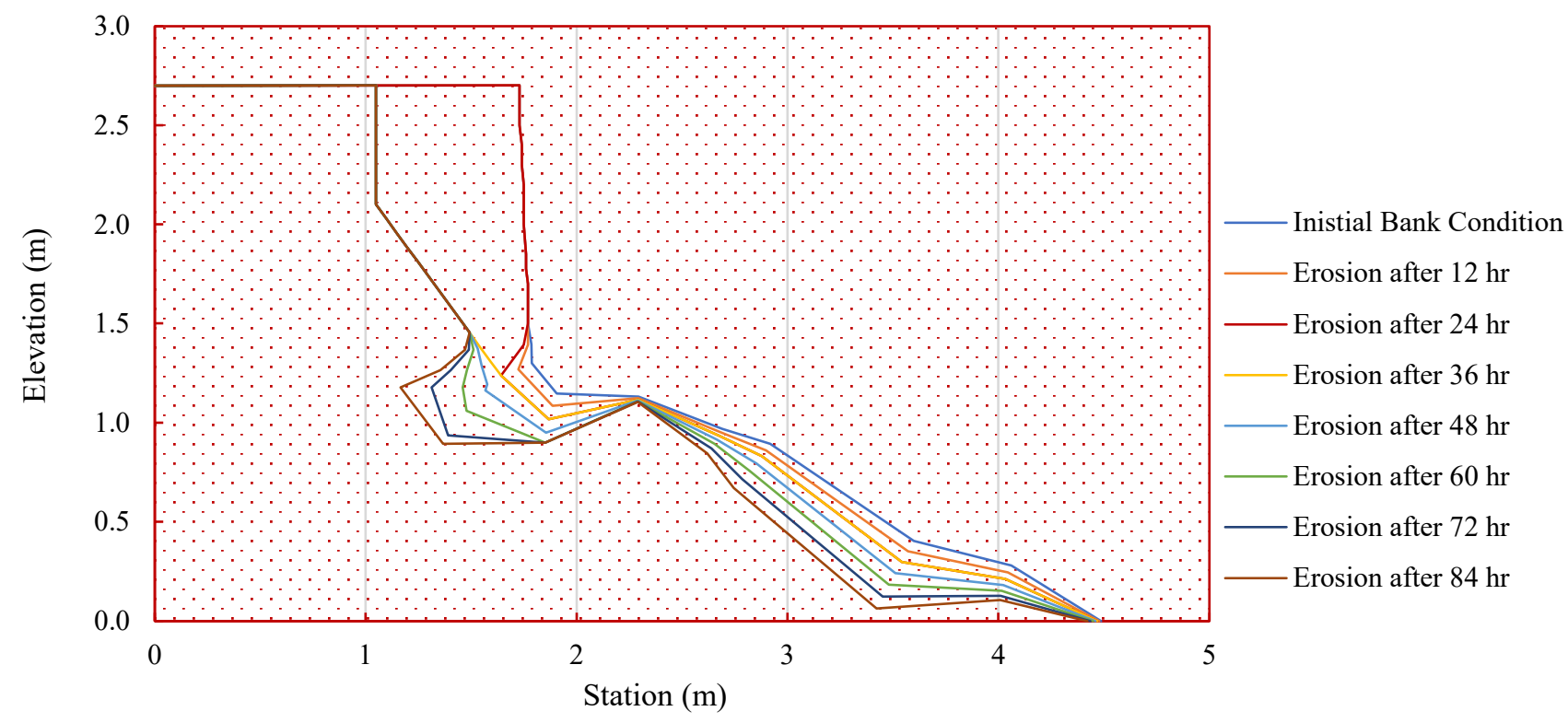

Figure 7. Stream bank geometry after failure occurs. 
Different protections can be used in the stream bank and bank toe, such as rip rap, geotextile, and live fascine. In this paper, rip rap applied for bank toe and geotextile for the stream bank as a protective measure to observe its effect on reducing stream bank and bank toe erosion. When the root-reinforcement model was run, the maximum rooting depth was determined to be $1 \mathrm{~m}$. Wet Meadow was selected with a plant age of 5 years. Then the value of $100 \%$ wet meadow was entered. After stream bank and bank toe protection was applied, the Protection Model gave an additional cohesion of $4.2 \mathrm{KPa}$ due to the application of roots. As for the Bank Stability Model, the new safety factor was changed from 0.93 (unstable) to 1.11 (conditionally stable), which indicates a reliable improvement in the bank protection process.

\section{Conclusion}

The gradient of erodibility of the Amu River is very high along its shores in Afghanistan. The dominant mechanism of failure was recognized as the mass failure of the stream bank. The Bank Stability and Toe-Erosion Model was useful to examine toe-erosion and stream bank stability wherever detailed data cannot be accessed. Also, the BSTEM model has the ability to evaluate the stream bank's responses to a root reinforcement model (Bank and Bank Toe Protection Model). The result of stream bank and bank toe protection was observed, and the results show that vegetation is very effective for stream bank stability, and it should be considered into any stabilization projects.

\section{References}

[1] Lavendel B (2002) "The Business of Ecological Restoration" Ecological Restoration (vol. 20, no. 3, pp. 173-178)

[2] Bernhardt ES, Palmer MA, Allan JD, Alexander G, Barnas K, et al. (2005) "Synthesizing U.S. River Restoration Efforts" Science (vol. 308, no. 5722, pp. 636-637) https://doi.org/10.1126/science.1109769

[3] Sadat SH (2015) "Modification of spur-dike with footing or pile-group to stabilize river morphology and reduce local scour" (PhD Dissertation) Nagoya, Japan, Nagoya Institute of Technology (https://nitech.repo.nii.ac.jp/?action=repository_action_common_down-

load\&item_id=3168\&item_no=1\&attribute_id=13\&file_no=2) Accessed: 1 November 2019

[4] Langendoen Eddy J., Simon Andrew (2008) "Modeling the Evolution of Incised Streams: Streambank Erosion (Part 2)" Journal of Hydraulic Engineering (vol. 134, no. 7, pp. 905915) 9429(2008)134:7(905) https://doi.org/10.1061/(ASCE)0733-

[5] Reisner DE, Pradeep T, Pradeep T (2014) "Aquananotechnology: Global Prospects," 1st ed. Florida, United States, CRC Press. 887 p. ISBN: 978-0-429-18563-2 (https://www.taylorfrancis.com/books/e/9780429185632) Accessed: 1 November 2019

[6] Simon A, Curini A, Darby SE, Langendoen EJ (2000) "Bank and near-bank processes in an incised channel" Geomorphology (vol. 35, no. 3, pp. 193-217) https://doi.org/ 10.1016/S0169-555X(00)00036-2
[7] Location of study area in Amu river (2018) (https://landlook.usgs.gov/viewer.html) Accessed: 27 June 2018

[8] Land Cover, Afghanistan (FAO) (2010) Food and Agriculture Organization (FAO) (http://www.un-spider.org/linksand-resources/data-sources/land-cover-afghanistan-fao) Accessed: 1 November 2019

[9] Ariathurai R, Arulanandan K (1978) "Erosion Rates of Cohesive Soils" Journal of the Hydraulics Division (vol. 104, no. 2, pp. 279-283)

[10] Klavon K, Fox G, Guertault L, Langendoen E, Enlow H, et al. (2017) "Evaluating a process-based model for use in streambank stabilization: insights on the Bank Stability and Toe Erosion Model (BSTEM)" Earth Surface Processes and Landforms (vol. 42, no. 1, pp. 191-213) https://doi.org/10.1002/esp.4073

[11] Hanson GJ, Simon A (2001) "Erodibility of cohesive streambeds in the loess area of the midwestern USA" Hydrological Processes (vol. 15, no. 1, pp. 23-38) https://doi.org/10.1002/hyp.149 